\title{
Influence of Microfinance Institution Technical Systems on the Performance of Dairy Farmers in Kakamega County, Kenya
}

\author{
Sangoro Oscar (Corresponding author) \\ School of Business and Economics, Mount Kenya University \\ P. O box 553-50100, Kakamega, Kenya \\ Gongera George \\ School of Business and Economics, Cooperative University \\ P. O Box 24814-00502, Karen, Kenya \\ Martin Onsiro Ronald \\ School of Business and Economics, Mount Kenya University \\ P. O Box 342-01000, Thika, Kenya \\ Phelista Njeru Wangui \\ School of Business and Economics, Mount Kenya University \\ P. O Box 342-01000, Thika, Kenya
}

\begin{abstract}
Objective of the study sought to investigate the influence of MFI technical systems on the performance of dairy farmers in Kakamega County. The aim of this objective was to find out how MFI technical systems have impacted on dairy farming performance in Kakamega County. Therefore, it was hypothesized that there is no significant relationship between the MFI technical systems and performance of dairy farmers in Kakamega County. MFI technical systems were measured by training, workshops, seminars which offer technical systems on marketing, breeding technologies, marketing, livestock health technologies and milk production technologies. This study adopted exploratory research design. The target population in this study consist of small scale dairy farmers deriving their capital from 17 micro-finance institutions.Descriptive and inferential statistics was used for the purpose of data analysis. To test the research hypotheses, Pearson correlation and regression was used to measure the general relationship between dependent and independent variables at significance level of 0.05 . The findings were presented using tables, models and charts. The findings revealed that Micro Finance Institutions systems have significant contribution to the performance of dairy farmers in Kakamega. Microfinance technical systems played significant role in the dairy farming performance as it enhances quality and quantity of dairy products through upscale of production technologies.
\end{abstract}

Keywords: Microfinance institution, Technical systems, Performance, Dairy Farmers

DOI: $10.7176 /$ RJFA/10-18-19

Publication date:September $30^{\text {th }} 2019$

\section{Introduction}

Nabiswa and Samba (2016) indicated the most challenges facing small scale dairy farmers in Kenya is lack of appropriate technical skill from feeding, disease control, marketing and production. This has reduced their returns and affected sustainability of dairy projects. According to Makokha (2015) most dairy farmers in Kakamega County lack technical skill in dairy production and this has affected milk yield in the County. Abdul-Moomin (2012) while investigating the role of microcredit on smallholder livestock production in Wa Municipality, Ghana, he recommended that microfinance should offer technical systems on breeding, feeding and other veterinary services. Mutai and Osborn (2014) as well as Madlani (2013) asserted that microfinance and other institutions should provide more training programmes so as to uplift the dairy sector which has suffered due to proper awareness. This was results to increase in production and improve the productivity of milk. 


\subsection{LITERATURE REVIEW}

In Zimbabwe, Zindiye (2008) argues that the SME sector attracts a low priority to financial training and are often unwilling to participate in programs that require them to finance the costs these enterprises eventually are weak in cash management, marketing strategies and finance. The study further concluded that business supported by MFIs should be trained to ensure their growth. OECD (2013) found out that in New Zealand, United Kingdom, Belgium, Poland, Turkey and Canada, the following reasons why owners of agribusinesses do not participate in training programs: lack of time, very expensive and difficulty in accessing its relevance to the needs of the enterprise. Furthermore a conclusion was drawn that firms that did not participate in these training programs did so because they believed they already have or can recruit the skills the enterprise required. Therefore microfinance institutions need to create ways of measuring the impact of financial skills training to the SMEs.

However, Wright (2000) is not enthusiastic about the role of microfinance institution training to businesses supported and thinks that these funds should be diverted to other projects desperately needed such as health of the people in an organization and there is inadequate learning from the training programs offered by Microfinance Institutions funds could be used in other projects that might help the businesses more. Mbithi (2016) attested that even though MFI training is effective on the performance of businesses supported, most of MFIs do not explicitly budget for their clients. This means that most of the MFIs are limited to provide technical systems and training as financial obligation is prioritize first.

Microfinance Institutions need to train and provide technical systems to owners to have skills for specific production, business management and access to markets in order to make profits from the financial resources they receive. Financial skills training can improve the ability of the low-income earners to operate enterprises either directly or indirectly. Complexity of financial decisions requires that business owners are able to make informed choices on saving, borrowing, spending and investing their money (OECD, 2013). It is therefore important to investigate the influence of MFI technical and training systems on the performance of dairy farming businesses as it is often these vulnerable businesses affected by lack of financial capability. The effects of a lack of financial capability as highlighted by McQuid and Egdell (2011) are not only financial but may lead to wider problems for the individual, household and beyond, including debt, higher stress and reduced wellbeing.

Kenduiwa, Mwonya and Kinuthia (2016) used a cross sectional survey research design to investigate influence of smallholder dairy farmers' participation in microfinance on dairy farming in Longisa sub-county, Bomet County, Kenya. Simple random sampling was used to select 152 respondents for study. The questionnaire used to collect data was developed by the researcher and validated by experts in applied community development. The study revealed that training has a significant and positive influence on productivity of dairy farmers in the study area. However, the study did not indicate which specific productivity indicators were measured in the study to arrive at the conclusion.

Kimutai and Kipchumba (2016) sought to determine the effect of provision of loans and training systems on farmers' livelihood by financial association in the North Rift Region, Kenya. The study employed descriptive survey and explanatory research design. The target population of this study comprised 12,745 members/farmers drawn from 8 financial service associations operating within North Rift Region. The study used stratified sampling technique to select the 387 members as the study sample size. The findings of the study revealed that training systems impact positively on the livelihood of dairy farmers. The study did not target microfinance institution but also targeted other financial institution such as SACCOs which have the capacity to upscale dairy productivity. The study also did not measure performance of dairy farmers but it was based on household livelihood.

Mutua (2017) carried out a study to show the effect of Microfinance systems on poverty reduction in Makueni County. Descriptive research design was adopted. The study targeted 6 deposit taking institutions in Makueni County. Systematic simple random sampling method was used to select 244 MFI members from the deposit taking microfinance. Primary data was collected using questionnaires and presented by descriptive statistics methods like pie charts and graphs. The study found that Microfinance training has positive and significant effect on Poverty reduction in Makueni County. One of the key shortcomings of the study was that it sought to investigate effect of MFI systems on poverty reduction rather than on performance of dairy farmers. Therefore, the study did not also establish the effect of technical systems offered by MFI.

Chole (2017) assessed the effect of systems offered by Microfinance Institutions (MFIs) on the performance of MSEs in Kariobangi Light Industry Nairobi, Kenya. This study was conducted in Kariobangi Light Industries, in Nairobi County and targeted operators of MSEs. The study adopted descriptive research design targeting a 
complete census of 210 MSEs. Primary data was collected using structure questionnaires. The study findings revealed MFI training systems have not contributed positively. The study recommends there is need for MFIs and MSEs stakeholders to come up with measures of addressing the poor performing training component of MFIs systems in Kenya.

Rotich, Lagat and Kogei (2015) reviewed the effects of microfinance systems on the performance of MSMEs using an explanatory research design. The study targeted 429 MSMEs registered by the Kiambu Municipal Council and sampled 270 enterprises. The study utilized multiple regression analysis set draw inferences on the study using SPSS statistical package. The study found managerial training to be statistically significant in determining the performance of MSMEs. This study concludes that increasing provision levels of micro finance will result in increased performance of micro enterprise. The study limited itself to managerial training of Micro, small and medium enterprises leaving out general training and technical systems that may have impact on performance. The study also did not sample any of dairy farming respondents.

\subsection{Knowledge-based Theory}

Knowledge-based theory was postulated by Penrose (1959). This theory underlines the role of knowledge in increasing productivity within different enterprises and the economy. Therefore, enterprises and economies which have highly educated and financially trained manpower are likely to be high performers compared to those that lack these key resources. In the finance context, the reason is that well-educated and financially trained dairy farmers are proactive and quick at learning and applying new skills to improve efficiency, productivity, risk taking and innovativeness of their enterprises (Brue,et al. 2009).

The knowledge-based theory distinguishes between two types of learning on the basis of the mode or context within which it occurs. First, there is exploitative learning, which is external to the dairy farmers and therefore must be acquired and its acquisition is dependent on the duration, content, facilitator and follow-up programme. Second, it is important to acquire explorative learning, which obtains from inside the enterprises and thus can occur only through internal experiments and hence is experiential in nature. Therefore, this study relates to acquisition of knowledge by dairy farmers and their technical systems. Technical systems and learning by doing are fundamental processes of knowledge development for dairy farmers. Technical systems and training can be used to integrate the learning and attitudes with behavior. From a strategic point of view, well informed dairy farmers could easily make correct decisions concerning the growth of their enterprises. Dairy farmers with such trainings manifest various knowledge bases on breeding, milk production, marketing, feeding, disease control and financial management. These decisions invariably distinguish between high performing and low performing enterprises (Diamond, 2005)

Technical systems and training, therefore, impact upon breeding, milk production, marketing and enterprise development of the dairy farmers. Moreover, it influences the vision, mission, culture, and values of the enterprises. Therefore, the rationale of using this theory was that it underscores the vitality of the level of technical systems and training of the dairy farmers which positively impact on their performance.

\subsection{RESEARCH METHODOLOGY AND DESIGN}

This study adopted exploratory research design. The design was chosen because it design establishes causal relationships between variables. The emphasis is on studying a situation or a problem in order to explain the relationship between variables (Saunders, Lewis \& Thornhill, 2007).Creswell (2005) asserts that explanatory research design can be used to predict an outcome such as performance of dairy farmers. In this case it involved gathering of data to determine the influence of microfinance institution systems on the dairy farming performance.The study carried out in Kakamega County which is one of the forty seven counties in Kenya. The county has $12 \mathrm{sub}$ counties. The study particularly dealt with dairy farmers who get their funding from Microfinance institutions which has a population of 1310.Samples were chosen using stratified sampling to ensure each sub county in the county was proportionally represented. For primary data Krejcie and Morgan formula was used

$\mathrm{S}=\frac{\mathrm{X}^{2} \mathrm{NP}(1-\mathrm{P})}{\mathrm{d}^{2}(\mathrm{~N}-1)+\mathrm{X}^{2} \mathrm{P}(1-\mathrm{P})}$

Where;

$\mathrm{S}$ is the desired sample size

$\mathrm{X}^{2}$ is the table value of chi-square for one degree of freedom at desired confidence level which is $1.96 \mathrm{X} 1.96=$ 3.841 
$\mathrm{N}$ is the population size (1310)

$\mathrm{P}$ is the population proportion assumed to be 0.5 since this will provide maximum sample size and $\mathrm{d}$ is the degree of accuracy expressed as a proportion 0.05

$\mathrm{S}=\quad 3.8416 \times 1310 \times 0.5(1-0.5)$ $=297.2250703$ which is 297 Respondents. $0.05^{2}(1310-1)+3.8416 \times 0.5(1-0.5)$

The distribution per Sub County was done proportionally as shown in Table 1

Table 1: Sample size category

\begin{tabular}{lcc}
\hline Sub Counties & Target Population & Sample Size \\
\hline Kakamega Central & 408 & 20 \\
Kakamega South & 404 & 19 \\
Kakamega East & 403 & 20 \\
Mumias East & 516 & 25 \\
Mumias West & 627 & 30 \\
Matungu & 494 & 24 \\
Lugari & 675 & 33 \\
Navokholo & 625 & 30 \\
Malava & 704 & 34 \\
Likuyani & 709 & 35 \\
Khwisero & 295 & 14 \\
Butere & 274 & 13 \\
Total & $\mathbf{1 3 1 0}$ & $\mathbf{2 9 7}$ \\
\hline
\end{tabular}

Source: Researcher (2019)

\subsection{RESEARCH FINDINGS, ANALYSIS AND PRESENTATION}

\section{Response Rate}

Two hundred and ninety seven questionnaires were issued to dairy farmers of sampled MFI. Two hundred and fifty eight were returned. The response rate was $88.9 \%$. The questionnaire yielded over $60 \%$ of response rate which is satisfactorily according to Mugenda and Mugenda (2008).

\subsubsection{Microfinance institutions Technical systems}

The sampled respondents were asked to indicate the extent of their agreement on five statements related to Microfinance institutions technical systems. The response range from 1 strongly disagree, 2-disagree, Uundecided, 4-agree and 5-strongly agree. The metric means and standard deviation of the six statements were also computed. 
Table 2: Technical systems Descriptive Results

\begin{tabular}{|c|c|c|c|c|c|c|c|}
\hline Technical systems & SD\% (f) & D\% (f) & U\% (f) & A\% (f) & $\begin{array}{l}\text { SA\% } \\
\text { (f) }\end{array}$ & Mean & SDV \\
\hline $\begin{array}{l}\text { MFI aggressively give technical } \\
\text { systems which are beneficial to dairy } \\
\text { farming }\end{array}$ & $\begin{array}{c}3.5 \% \\
(9)\end{array}$ & & & $\begin{array}{c}27.5 \% \\
(71)\end{array}$ & $\begin{array}{c}56.6 \% \\
(146)\end{array}$ & 4.26 & 1.09 \\
\hline $\begin{array}{l}\text { MFIs assist farmers in obtaining } \\
\text { inputs for the dairy farming } \\
\text { Technical systems obtained from }\end{array}$ & $\begin{array}{c}3.1 \% \\
(8)\end{array}$ & $\begin{array}{l}4.7 \% \\
(12)\end{array}$ & $\begin{array}{l}5 \% \\
(13)\end{array}$ & $\begin{array}{c}27.9 \% \\
(72)\end{array}$ & $\begin{array}{l}58.9 \% \\
(152)\end{array}$ & 4.35 & 1.00 \\
\hline $\begin{array}{l}\text { MFI have enabled me to change } \\
\text { dairy production system }\end{array}$ & $\begin{array}{c}1.9 \% \\
(5)\end{array}$ & & & $\begin{array}{l}24 \% \\
(62)\end{array}$ & $\begin{array}{c}60.9 \% \\
(157)\end{array}$ & 4.34 & 1.03 \\
\hline $\begin{array}{l}\text { MFIs assist farmers in the mode of } \\
\text { marketing of the dairy products }\end{array}$ & $\begin{array}{l}1.9 \% \\
(5)\end{array}$ & $\begin{array}{l}5.8 \% \\
(15)\end{array}$ & $\begin{array}{l}10.1 \% \\
(26)\end{array}$ & $\begin{array}{l}23.6 \% \\
(61)\end{array}$ & $\begin{array}{l}58.5 \% \\
(151)\end{array}$ & 4.31 & 1.00 \\
\hline $\begin{array}{l}\text { MFIs organize trainings for its } \\
\text { members on various technologies to } \\
\text { improve productivity }\end{array}$ & $\begin{array}{l}6.2 \% \\
(16)\end{array}$ & $\begin{array}{l}8.9 \% \\
(23)\end{array}$ & $\begin{array}{l}14 \% \\
(36)\end{array}$ & $\begin{array}{l}23.3 \% \\
(60)\end{array}$ & $\begin{array}{l}48.1 \% \\
(124)\end{array}$ & 3.98 & 1.24 \\
\hline $\begin{array}{l}\text { MFIs collaborate with other } \\
\text { institution in providing technical } \\
\text { systems to dairy farmers }\end{array}$ & $\begin{array}{c}10.3 \% \\
(27)\end{array}$ & $\begin{array}{c}12.8 \% \\
(33)\end{array}$ & $\begin{array}{c}18.9 \% \\
(49)\end{array}$ & $\begin{array}{c}22.8 \% \\
(59)\end{array}$ & $\begin{array}{c}35.3 \% \\
(91)\end{array}$ & 3.60 & 1.35 \\
\hline
\end{tabular}

\section{Source: Field Data (2019)}

From Table 2, $27.5 \%(71)$ and 56.6\%(146) of the sampled respondents agreed and strongly agreed respectively that their MFI aggressively give technical systems which are beneficial to dairy farming. A mean of 4.26 implied that MFI aggressively give technical systems which are beneficial to dairy farming. The results also revealed that $27.9 \%(72)$ and $58.9 \%(152)$ of the sampled respondents agreed and strongly agreed respectively that MFIs assist farmers in obtaining inputs for the dairy farming. A mean of 4.35 indicated that MFIs assist farmers in obtaining inputs for the dairy farming. The results further revealed that $60.9 \%$ (157) of the sampled respondents strongly agreed that technical systems obtained from MFI have enabled me to change dairy production system while $24 \%(62)$ agreed that on the same. A mean of 4.34 implied that technical systems obtained from MFI have enabled me to change dairy production system.

The results further revealed that $23.6 \%$ ( 61$)$ and $58.5 \%$ ( 151) of the sampled agreed and strongly agreed that their MFIs assist farmers in the mode of marketing of the dairy products. A mean of 4.31 implies that MFIs assist farmers in the mode of marketing of the dairy products. Further, $48.1 \%$ ( 124) of the sampled respondents strongly agreed that MFIs organize trainings for its members on various technologies to improve productivity and $23.3 \%$ ( 60 ) agreed on the same. A mean of 3.98 implied that most of MFIs organize trainings for its members on various technologies to improve productivity.

\section{A simple linear regression between Technical systems and Dairy farmer performance}

A simple linear regression was carried to assess the influence of Technical systems on the dairy farmer performance in Kakamega County. This entails composite variable of Technical systems index which was mean obtained from six metrics that was used to measure Technical systems in this study. Similarly, the composite value of dairy farmer performance was obtained by getting mean of five metrics that was used to measure dairy farmer performance. The results are presented in Table 19. 
Table 3: Regression Analysis of Technical systems

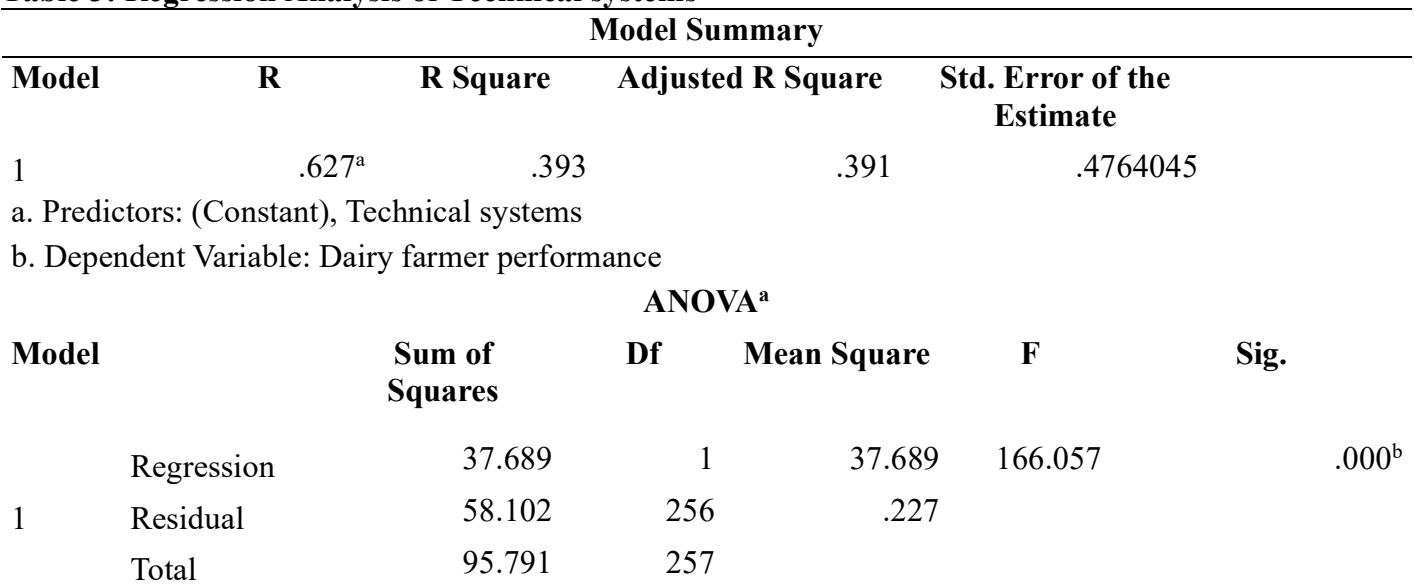

a. Dependent Variable: Technical systems

b. Predictors: (Constant), Dairy farmer performance

$\begin{array}{lcccrr}\text { Model } & \text { Unstandardized Coefficients } & \begin{array}{c}\text { Coefficients } \\ \text { Standardized } \\ \text { Coefficients }\end{array} & \text { T } & \text { Sig. } \\ & \text { B } & \text { Std. Error } & \text { Beta } & & \\ \text { (Constant) } & 1.843 & .121 & & 15.242 & .000 \\ \text { Technical systems } & .446 & .035 & .627 & 12.886 & .000 \\ \text { a. Dependent Variable: Dairy farmer performance } & & & & \end{array}$

Source: Field Data (2019)

The proportion of variance in Dairy farmer performance explained by the independent variable (Technical systems) is $39.3 \%\left(\mathrm{R}^{2}=0.393\right)$. From the findings, the $\mathrm{F}$ ratio is greater than 1 , as indicated by a value of 166.057 , which means that improvement due to fitting the model is much greater than the model inaccuracies $(\mathrm{F}(1,257)=166.057$, $\mathrm{P}=0.000)$.. This implies that technical service is useful predictor of dairy farmer performance. From the findings presented in Table above, technical systems carried positive significant predictive power $(B=0.446, p=.000)$ implying that a unit change in technical systems would result to significant change in dairy farmer performance value by 0.446 units. Therefore, the linear regression results indicated that there was a statistically significant positive relationship between technical systems and dairy farmer performance. The study developed analytical model for predicting dairy farmer performance from technical systems is stated in the form of:

Dairy farmer performance $=1.843+0.446$ Technical systems

\section{SUMMARY, CONCLUSION AND RECOMMENDATIONS}

\section{Summary of findings}

The objective of the study was to investigate the effect of MFI technical systems on the performance of dairy farmers in Kakamega County. Descriptive results indicated that MFI were offering to great extent technical systems to their clients. This included information on dairy farming input especially feed and fodder, breeding technologies such as Artificial Insemination (A.I). The study also found that MFI organized capacity building with dairy farmers through training as well as collaboration with other institution and organization dealing with dairy value chain. This has seen farmers accessing market; add value to their milk such as yoghurt and other by-products. The income of farmers has increased due to increase in milk quantity and accessibility of market. The results indicated that Technical systems had a statistically significant influence on the dairy farming performance in Kakamega. The hypothesis that there is no significant relationship between the Technical systems on the dairy farming performance was rejected by the study. 
Conclusion

Objective of the study sought to test the first null hypothesis which posits: There is no significant relationship between the MFI technical systems and performance of dairy farmers in Kakamega County. From the findings, there was sufficient evidence to reject the null hypothesis and conclude that there is significant relationship between the MFI technical systems and performance of dairy farmers in Kakamega County. Increase in technical systems from Micro Finance Institutions such as feed and fodder, breed technologies, marketing, milking technologies and up scaling of the technologies. Most small scale farmers are unable to access technical systems especially extension systems and capacity building as this has impact dairy farming performance. Both governments (National and County) have been unable to offer this service effectively and therefore, alternative actors such as Micro Finance Institutions have significant role to play to ensure farmers who are their client receive the required technical systems so as to service the credit and the same time to meet their livelihood needs. Most of the Micro Finance Institutions extending Micro Finance Institutions systems to dairy farmers in Kakamega County have aggressively offered technical systems that are beneficial to dairy farmers.

\section{Recommendations}

From the conclusion, the following recommendations were made in respective to the objective of the study

Offering financial systems alone is not assurance that dairy farming performance would increase. It was found that some of the Micro Finance Institutions were offering technical systems while others were not. The study recommended that Micro Finance Institutions need to improve on the technical systems offered to dairy as not all Micro Finance Institutions were found to offer each aspect of technical systems that is needed to improve dairy farming performance. Specifically, the Micro Finance Institutions need to collaborate with other organization and institution both government and non-government to ensure that farmers receive technical systems which will support dairy farmers. Through this collaboration, Micro Finance Institutions would ensure that their systems are been utilized in a profitable way therefore achieve social and economic mission of Micro Finance Institutions. The government should make it compulsory for Micro Finance Institutions offer credit to dairy farmers to support technical systems through corporate social responsible programs. On the other hands, dairy farmers should be support technical systems offered by Micro Finance Institutions especially capacity building through self-help groups formations.

\section{References}

Abdul-Moomin, A. (2012). The impact of microcredit on smallholder livestock production in Wa Municipality: a case of the livestock development project (Doctoral dissertation).

Abor, J., \&Quartey, P. (2010).Issues in SME development in Ghana and South Africa.International research journal of finance and economics, 39(6), 215-228.

Aggarwal, S., Klapper, L., \& Singer, D. (2012).Financing businesses in Africa: The role of microfinance.The World Bank.

Akanni, K. A. (2007). Effect of micro-finance on small scale poultry business in South Western Nigeria.Emirates Journal of Food and Agriculture, 38-47.

Akisimire, R (2010). Microfinance credit terms and performance of SMEs in UGANDA: Acase study of SMEs in Mbarara Municipality. (Unpublished Master's Thesis), MakerereUniversity.

Akotey, J.O. (2015). The Impact of Microinsurance on Household Welfare in Ghana.Doctor of Philosophy Degree in Development Finance, Stellenbosch University.

Ali, A. (2007). The impact of micro credit on livestock enterprise development in district Abbottabad (A case of SRSP micro credit programme).

Amsi, F., Ngare, P., Imo, P., \&Gachie, M. (2017).Effect of microfinance credit on SMEs financial performance in Kenya.Journal of Emerging Trends in Economics and Management Sciences, 8(1), 48-61.

Anyanwu, C. M. (2004, November). Microfinance institutions in Nigeria: policy, practice and potentials. In G24 Workshop on "Constraints to Growth in Sub Saharan Africa," Pretoria, South Africa (pp. 1-31).

Apalia, E. A. (2017). The role of micro finance institutions in the Kenyan economy: A case of Kisii town, Nyanza. International Academic Journal of Procurement and Supply Chain Management, 2(1), 16-33.

Apalia, E. A. (2017). The role of micro finance institutions in the Kenyan economy: A case of Kisii town, Nyanza. International Academic Journal of Procurementand Supply Chain Management, 2 (1), 16-33

Armendariz, B., \& Morduch, J. (2004). Microfinance-where do we stand?. Palgrave.

Avortri, C., \&Wereko, T. B. (2016). The Effect of Systems of Micro Financial Institutions on their Financial Performance: A View from Ghana. International Journal of Scientific Research and Innovative Technology, 3(7), 25-42. 
Ayertey, M. N. (2008). Microfinance and its impact on selected Districts in Eastern Region of Ghana (Doctoral dissertation, a thesis submitted to the department of economics for the degree of Mphil, KNUST, Kumasi, Ghana Brau, JC \&Woller, GM (2004) Microfinance: A Comprehensive Review of the Existing Literature, Journal of Entrepreneurial Finance and Business Ventures, 9 (1), 1-26).

Bass, J \& Henderson, K (2011). Innovations in Microfinance: The Microfinance experience withsavings mobilization. (p.10). Weidemann Associates, Inc.

Bateman, M. (2010). Why doesn't microfinance work?: The destructive rise of local neoliberalism. Zed Books Ltd.

Bello, G. B. (2012). An Assessment of The Contributions of Microfinance on the Growth of Small and Medium Enterprises (SMEs) in Nigeria. ADVANCES IN GLOBAL BUSINESS RESEARCH.

Bendig, M., \&Arun, T. (2016). Uptake of Multiple Microinsurance Schemes: Evidence from Sri Lanka. The Geneva Papers on Risk and Insurance-Issues and Practice, 41(2), 205-224.

Bhattacharya, S., \&Londhe, B. R. (2014). Micro entrepreneurship: Sources of finance \& related constraints. Procedia Economics and Finance, 11, 775-783.

Biwott and Tuwei (2016). Does provision of loans and training systems by dairy farmers association affect farmers livelihood in north rift region, Kenya? International Journal Of Economics, Commerce And Management 2(6), 312-324

Biwott, D. \&Tuwei, R. (2016). Does Provision Of Loans And Training Systems By Dairy Farmers Association Affect Farmers Livelihood In North Rift Region, Kenya? International Journal of Business and Commerce 4(2), 67-77

Blavy, M. R., Basu, M. A., \&Yülek, M. Â. (2004).Microfinance in Africa: Experience and Lessons from Selected African Countries (EPub) (No. 4-174). International Monetary Fund.

Carlton, A., \& Wien, L. (2001). Microfinance in Uganda. L\&R Sozialforschung.

Chole, L. (2017). Effect Of Systems Offered By Microfinance Institutions On Performance Of Micro And Small EnterprisesinKariobangi Light Industry In Nairobi, Kenya (Doctoral dissertation, KCA University).

Churchill, C., \&Matul, M. (2012). Protecting the Poor Amicroinsurance compendium Volume II.

Cooper, R., \& Schindler, P. (2006).Marketing Research.New York: McGraw-Hill.

County Government of Kakamega (CGOK), (2017).One Cow Initiative Strategic Report, 2017.Kakamega, Kenya.

Creswell, J. W. (2003). Research Design: Qualitative, Quantitative and Mixed Methods Approaches (2nd Ed).London: Sage Publications. Creswell, J. W. (2005). Educational research: Planning, conducting, and evaluating quantitative and qualitative research (2nd Ed.). Upper Saddle River, NJ: Pearson.

DaunerGardiol, I. (2004). Cash or cows?household saving and portfolio choices in developing countries: a case study of Nicaragua (Doctoral dissertation, Université de Lausanne, Faculté des hautesétudescommerciales).

Demirgüç-Kunt, A., Levine, R., \&Detragiache, E. (2008). Finance and economic development: The role of government. Policy working paper, 3955.

Dionne, G. (Ed.). (2013). Contributions to insurance economics (Vol. 13).Springer Science \& Business Media.

Elabed, G., \& Carter, M. R. (2015).Compound-risk aversion, ambiguity and the willingness to pay for microinsurance. Journal of Economic Behavior \& Organization, 118, 150-166.

Farrin, K., \& Miranda, M. J. (2015).A heterogeneous agent model of credit-linked index insurance and farm technology adoption.Journal of Development Economics, 116, 199-211.

Forbes, K. J., \& Chinn, M. D. (2004).A decomposition of global linkages in financial markets over time. Review of economics and statistics, 86(3), 705-722.

Gallardo, J. (2002). A framework for regulating microfinance institutions: the experience in Ghana and the Philippines. The World Bank.

Gathogo, P. K. (2014). The Effect of Microfinance Institutions on the Growth of Small Scale Enterprises in KiambuCounty(Doctoral dissertation, United States International University-Africa).

Garson, G. D. (2012). Testing statistical assumptions. Asheboro, NC: Statistical Associates Publishing.

Ghasemi, A., \&Zahediasl, S. (2012). Normality tests for statistical analysis: a guide for nonstatisticians. International journal of endocrinology and metabolism, 10(2), 486.

Girabi, F., \&Mwakaje, A. E. G. (2013). Impact of microfinance on smallholder farm productivity in Tanzania: The case of Iramba district. Asian Economic and Financial Review, 3(2), 227.

Gray,D, Saunders, M \&Goregaokar, H (2012). Success in challenging times: Key lessons for UK SMEs. (p.8). Kingston Smith.

Hassan, M. K., Gathenya, J., \&Iravo, M. (2017). Moderating Effect of Index Based Livestock Insurance on SocioCultural Factors Affecting Performance of Livestock Projects in North Eastern Kenya. International Journal of Academic Research in Business and Social Sciences, 7(3), 99-116. 
Henriksen, G. L., \&Svoldal, S. O. (2010). The impact of providing business training to microfinance clients: empirical evidence from Tanzania (Master's thesis).

Hosseini, S. M., DaneshvarKakhki, M., Dourandish, A., \&Ghorbani, M. (2018). Agricultural I nsurance and I ntensification I nvestment: $\mathrm{C}$ ase $\mathrm{S}$ tudy of KhorasanRazavi P rovince.

Hosseini, S. M., DaneshvarKakhki, M., Dourandish, A., \&Ghorbani, M. (2018). Agricultural I nsurance and I ntensification I nvestment: $\mathrm{C}$ ase $\mathrm{S}$ tudy of KhorasanRazavi P rovince.

Hussain, J., Mahmood, S., \& Scott, J. (2018). Gender, Microcredit and Poverty Alleviation in a Developing Country: The Case of Women Entrepreneurs in Pakistan. Journal of International Development.

Ibrahim, A. H., \& Bauer, S. (2013). Access to micro credit and its impact on farm profit among rural farmers in dryland of Sudan. Global Advanced Research Journal of Agricultural Science, 2(3), 88-102.

Ibrahim, A. H., \& Bauer, S. (2013). Access to micro credit and its impact on farm profit among rural farmers in dryland of Sudan. Global Advanced Research Journal of Agricultural Science, 2(3), 88-102.

Ibrahim, S. S., \&Aliero, H. M. (2012). An analysis of farmers access to formal credit in the rural areas of Nigeria. African journal of agricultural research, 7(47), 6249-6253.

Ibtissem, B., \&Bouri, A. (2013). Credit risk management in microfinance: The conceptual framework. $A C R N$ Journal of Finance and Risk Perspectives, 2(1), 9-24.

Insurance regulatory Authority (IRA), (2014). The Kenya Microinsurance Policy Framework paper. Available from: www.ira.go.ke

Issa, F. O. (2013). Building the capacity of agricultural extension personnel for effective implementation of agricultural transformation agenda in Nigeria.Journal of Agricultural Extension, 17(1), 78-88.

Jalo, J. N., Onu, J. I., Margwa, R. S., \& Dire, B. (2015). Effects of socio-economic characteristics on savings among farmers in cooperative societies: Observations from Numan and Demsa Local Government Area of Adamawa State, Nigeria. Journal of Agricultural and Crop Research, 3(7), 117-122.

Jooste, C., \&Fourie, B. (2009). The role of strategic leadership in effective strategy implementation: Perceptions of South African strategic leaders. Southern African Business Review, 13(3).

Kalui, F. M., \&Omwansa, D. M. (2015).Effects of Microfinance Institutions' Products on Financial Performance of Small and Medium Enterprises; A Case of Machakos Town, Kenya.Journal of Business and Management, 17(4), 50-57.

Kariuki, S. N., Namusonge, G. S., \&Orwa, G. O. (2015). Determinants of corporate cash holdings: evidence from private manufacturing firms in Kenya. International Journal of Advanced Research in Management and Social Sciences, 4(6), 15-33.

Karlan, D. S., \& Valdivia, M. (2006). Teaching Entrepreneurship: Impact of Business Training on Microfinance Clients and Institutions, r. Yale University Eco! nomic Growth Center Discussion Paper No. 941. Center for Global Development Working Paper, (108).

Kenduiwa, A., Mwonya, R., \&Kinuthia, L. (2016). Influence of Smallholder Dairy Farmers Participation in Microfinance on Breed Improvement in Dairy farming in Longisa Sub County, Bomet County, Kenya. $J$. Agric. Vet. Sci, 9(7), 66-75.

Kenduiwa, A., Mwonya, R., \&Kinuthia, L. (2016). Influence of Smallholder Dairy Farmers Participation in Microfinance on Breed Improvement in Dairy farming in Longisa Sub County, Bomet County, Kenya. $J$. Agric. Vet. Sci, 9(7), 66-75.

Kibet, L. K., Mutai, B. K., Ouma, D. E., Ouma, S. A., \&Owuor, G. (2009). Determinants of household saving: Case study of smallholder farmers, entrepreneurs and teachers in rural areas of Kenya. Journal of Development and Agricultural Economics, 1(7), 137-143.

Kilelu, C. W., Klerkx, L., \&Leeuwis, C. (2013).Unravelling the role of innovation platforms in supporting coevolution of innovation: Contributions and tensions in a smallholder dairy development programme.Agricultural systems, 118, 65-77.

Kimaro, E. G., Mlangwa, J. E. D., Lyimo-Macha, J., \&Kimaro, J. G. (2013). The influence of women groups on income obtained from small-scale dairy cattle production: Acase of Arumeru District, Tanzania. Livestock Research for Rural Development, 25(4), 21-27.

Kisaka, S. E., \&Mwewa, N. M. (2014).Effects of Micro-credit, Micro-savings, and Training on the Growth of Small and Medium Enterprises in Machakos County in Kenya.Research Journal of Finance and Accounting, 5(7), 43-49.

Kristjanson, P., Waters-Bayer, A., Johnson, N., Tipilda, A., Njuki, J., Baltenweck, I., ...\& MacMillan, S. (2014). Livestock and women's livelihoods.InGender in agriculture (pp. 209-233). Springer, Dordrecht.

Kurgat, P. (2007). The role of savings in Microfinance Institutions a case of KWFT. Unpublished Master's Thesis), Solvay Brussels School of Economics and Management. 
Leedy, P. \&Ormrod, J. (2005).A handbook for teacher research from design to implementation. New Jersey: Pearson Education.

Liman, N., Hashim, M. K., \&Arshad, D. (2017).A Study on the Types of Microfinance Institutions in Nigeria.MAYFEB Journal of Business and Management, 2.

Loewe, M., \&Zaccar, C. (2014).Microinsurance in Western Asia. Available at SSRN 2610108.

Luyirika, M. N. (2010). The role of microfinance in the socio-economic development of women in a community: a case study of Mpigi Town Council in Uganda (Doctoral dissertation, University of South Africa).

Madlani, M. B. (2013). Women Entrepreneurship and Rural Development.Journal of Research in Commerce and Management, 2 (12), 94-98.

Maia, A. G., Eusebio, G., \&Silveira, R. L. (2016). Impact of microcredit on small-farm agricultural production: evidence from Brazil. In Agricultural \& Applied Economics Association Annual Meeting, Boston.[Google Scholar].

Makokha, S. N. (2005). Analysis of factors influencing the adoption of dairy technologies in western Kenya.University of Nairobi, Nairobi, Kenya.

Mathur, S. (2012).Micro Insurance-A Powerful Tool to Empower Poor. Management Insight, 6(2).

Matiangi, J. (2016). The Effect of Microfinance Systems On Financial Performance of Small and Medium Enterprises in Kawangware, Nairobi County- Kenya. Unpublished MBA Project University of Nairobi

Matul, M., McCord, M. J., Phily, C., \& Harms, J. (2010).The Landscape of Microinsurance in Africa.Working Paper No. 4. Geneva: ILO

Mbithi, N. K.(2016). Effectiveness Of Microfinance Training Programmes On Women's Financial Skills In SelfHelp Groups In Limuru Constituency, Kiambu County, Kenya.

Meyer, J. (2013). Track record of financial institutions in assessing the poor in Asia.ADBresearch institute paper, No. 49, September 30, 2013.

Mgbakor, M. N., Uzendu, P. O., \&Ndubisi, D. O. (2014).Sources of Agricultural Credit to Small-Scale Farmers in Ezeagu Local Government Area of Enugu State, Nigeria.IOSR Journal of Agriculture and Veterinary Science (IOSR-JAVS), 7(8), 1-8.

Meier zuSelhausen, F., \&Musinguzi, J. (2011).The current performance of business and operations of rural Microfinance Institutions (MFIs) in the Rwenzori region. Rwenzori Journal, 1(1), 77-99.

Mkpado, M., \&Arene, C. J. (2007). Effects of democratization of group administration on the sustainability of agricultural micro credit groups in Nigeria. International Journal of Rural Studies, 14(2).

Mohammed, A. H., \& Mukhtar, S. (2012). The prospects of micro-insurance in the rural areas of Nigeria. European Scientific Journal, 8 (3), 66, 76.

Mohamad, M. (2011). Mobile Microfinance and empowerment: the case of e-Masary for financial inclusion in Egypt. Strategic Foresight Group, 2(11).

Montgomery, D. C. (2001).Design and analysis of experiments.ed. John Wiley \& Sons, 52, 218-286.

Moruf, O. L. A. D. E. J. O. (2013). Evaluation of the Nigerian microfinance banks credit administration on small and medium scale enterprises operations. Journal of International Review of Management and Business Research, 2(2).

Mugenda, A. (2008). Social science research: Conception, methodology and analysis. Nairobi: Kenya Applied Research and Training Systems.

Mugenda, O. M., \&Mugenda, A. G. AG (2008) Research Methods: Quantitative and Qualitative Approaches: Nairobi. African Centre for Technology Studies.

Müller, S., Ramm, G., \& Steinmann, R. (2014).Agriculture, Microinsurance and Rural Development. A thematic paper. Frankfurt/Brussels: GIZ/Microinsurance Network.

Mutai, R. K., \& Osborn, A. G. (2014). Impact Of Microfinance On Economic Empowerment Of Women: The Case Of Microfinance Institutions' clients In Narok Town. Journal of Global Business \& Economics, 8(1).

Mutisya, M., Bichanga, W., \&Olweny, T. (2014). Effect Of Microfinance Systems On Performance Of Businesses Owned By Women In Kibera Slum, Nairobi County, International Journal of Business and Commerce $4(1), 1-18$

Mutua, F. N. (2017). Effect of microfinance systems on poverty reduction in Makueni County (Doctoral dissertation).

Natarajan, K. (2004). Can Group Lending Overcome Adverse Selection Problems?. Centre for Financial and Management Studies, SOAS, Working Paper.

Ndirangu, T. M. (2015). Microinsurance strategies adopted by Kenyan Insurance companies to increase sustainable competitive advantage. 
Ndungu, T. W., Omwamba, M., Muliro, P. S., \&Oosterwijk, G. (2016).Hygienic practices and critical control points along the milk collection chains in smallholder collection and bulking enterprises in Nakuru and Nyandarua Counties, Kenya.African Journal of Food Science, 10(11), 327-339.

Ngehnevu, C. B., \&Nembo, F. Z. (2010). The impact of Microfinance Institutions (MFIs) in the development of Small and Medium Size Businesses (SMEs) in Cameroon: A case study of CamCCUL. Retrieved 7 March 2015.

Ngera, M. (2018).Influence of Entrepreneurial Orientation on Microinsurance Uptake by Micro and Small Enterprises in Nairobi County, Kenya (Doctoral dissertation, JKUATCOHERD).

Ngumi, W. G. (2013). Use of mobile applications to gain sustainable competitive advantage at the Kenya Medical Supplies Authority (kemsa) (Doctoral dissertation, SCHOOL OF BUSINESS, UNIVERSITY OF NAIROBI).

Njamweah, D. M., \&Kidombo, H. (2018). Factors influencing saving behaviour among coffee farmers: A case of Manyatta Sub-county, Embu County, Kenya. International Academic Journal of Information Sciences and Project Management, 3(2), 291-302.

Njuguna, A. G., \&Arunga, A. (2013). Risk management practices: A survey of micro-insurance service providers in Kenya.

Njuguna, E., \&Nyairo, N. (2010). Formal conditions that affect agricultural credit supply to small-scale farmers in rural Kenya: case study for Kiambu County.

Nyakambi, A.G. (2014). Effect of microfinance credit on poverty alleviation at household level in NakuruCounty.Unpublished MBA project,university of Nairobi.

Nyokabi, S., Oosting, S. J., Bebe, B. O., Phelan, L., Bett, B., Lindahl, J., \& de Boer, I. J. M. (2018). The Kenyan dairy sector: stakeholder roles and relationships, and their impact on milk quality. In Farming systems: facing uncertainties and enhancing opportunities.

Obayelu, O. A. (2012). Saving behavior of rural households in Kwara State, Nigeria. Nigeria (February 4, 2012).

Oecd, W. (2013). UNCTAD (2013). Implications of global value chains for trade, investment, development and jobs, 20.

Ogodo, O. (2010). Kenyan Farmers Get Micro-insurance. Science and Development Network News.

Olaosebikan, O., \& Adams, M. (2014). Prospects for micro-insurance in promoting microCredit in sub Sahara Africa. Qualitative Research in Financial Markets, 6(3), 232-257.

Omondi, R. I. A. \&Jagongo, A. (2018).Microfinance systems and financial performance of small and medium enterprises of youth SMEs in Kisumu County, Kenya.International Academic Journal of Economics and Finance, 3(1), 24-43

Otiso, K. N., \&Omambia (2016). Effect Of Microfinance Practises On The Performance Of Women Owned EnTerprises In Bungoma Town. Baraton Interdisciplinary Research Journal (2016), 6(Special Issue), pp $127-133$

Park, H. M. (2015). Univariate analysis and normality test using SAS, Stata, and SPSS.

Ramsay, C. M., \&Arcila, L. D. (2013).Pricing Funeral (Burial) Insurance in a Microinsurance World with Emphasis on Africa. North American Actuarial Journal, 17(1), 63-81.

Rotich, I., Lagat, C., \&Kogei, J. (2015).Effects of microfinance systems on the performance of small and medium enterprises in Kenya.African Journal of Business Management, 9(5), 206-211.

Rotich, I., Lagat, C., \&Kogei, J. (2015).Effects of microfinance systems on the performance of small and medium enterprises in Kenya.African Journal of Business Management, 9(5), 206-211.

Rurangwa, E., Mburu, D., \&Mulyungi, P. (2018). Factors Affecting Savings of Small Scale Coffee Farmers in Rwanda International Journal of Innovative Research in Science, Engineering and Technology, 7(2), 3139

Saunders, M., Lewis, P., \&Thornhill, A. (2007).Research methods for business students (5th ed.). Britain: Prentice Hall.

Sebatta, C., Wamulume, M., \&Mwansakilwa, C. (2014).Determinants of smallholder farmers' access to agricultural finance in Zambia.Journal of Agricultural Science, 6(11), 63.

Segun, O., Hussein, A., Daniel, O., \&Olajide, A. (2015). Regulation of Microfinance Institutions in Africa Major Economies: A Comparative Analysis. The International Journal Of Business \& Management, 3(4), 77.

Shastri, R. K. (2009). Micro finance and poverty reduction in India (A comparative study with Asian Countries).African Journal of Business Management, 3(4), 136-140. 
Simon, M. (2013). Determinants of farmers"decision to access credit: the case of Zimbabwe. Russian Journal of Agricultural and Socio-Economic Sciences, 17(5).

Stiglitz, J. (2003). Globalization and the logic of international collective action: re-examining the Bretton Woods institutions. Governing globalization: Issues and institutions, 238-253.

Tabachnick, B. G. 8c Fidel], LS (2001).Using multivariate statistics.

Tabachnick, B. G., Fidell, L. S., \& Ullman, J. B. (2007). Using multivariate statistics (Vol. 5). Boston, MA: Pearson.

Tavakol, M., \&Dennick, R. (2011).Making sense of Cronbach's alpha. International journal of medical education, 2, 53.

Ter-Hemen, A. T. (2015).The challenges affecting dairy farmers in Kenya: a case study of dairy farmer groups in Njabini, Nyandarua County (Doctoral dissertation, United States International University-Africa).

Ter-Hemen, A. T. (2015). The challenges affecting dairy farmers in Kenya: a case study of dairy farmer groups in Njabini, Nyandarua County (Doctoral dissertation, United States International University-Africa).

Umuzigambeho, C. (2010). Baseline analysis of the gender dimensions in the provision of agricultural systems in Rwanda. Kigali: Gender Monitoring Office and UNIFEM.

Van Rooyen, C., Stewart, R., \& De Wet, T. (2012). The impact of microfinance in sub-Saharan Africa: a systematic review of the evidence. World Development, 40(11), 2249-2262.

Vogel, R. C. (1984). Savings mobilization: the forgotten half of rural finance.

Waithaka, T., Marangu, W. N., \&N'gondu, C. N. (2014). Entrepreneurship Development by micro finance institutions effect on the growth of micro and small enterprises in Nairobi Central Business District: A case of Jitegemea Credit Scheme Nairobi. European Journal of Business and Management, 6(13), 174184.

Weerasinghe, I. M. S., \&Dedunu, H. H. (2017).Impact of microfinance on living standard withreference to microfinance holders in KurunegalaDistrict.International Journal of Business Marketing and management (IJBMM). 2

Wright, G. (2000). Microfinance systems: Designing quality financial systems for the poor. Zed Books.

Yeboah E.H (2010). Microfinance in rural Ghana: A view from below. (Unpublished PHD Thesis), University of Birmingham.

Zindiye, S. (2008). An empirical investigation into the factors affecting the performance of Small and medium enterprises in the manufacturing sector of Harare, Zimbabwe (Doctoral dissertation, University of Fort Hare).

Zindiye, S. (2008). An empirical investigation into the factors affecting the performance of smalland medium enterprises in the manufacturing sector of Harare, Zimbabwe (Doctoral dissertation, University of Fort Hare). 